\title{
Efficacy of Vitamin C Vaginal Suppository in Treatment of Bacterial Vaginosis a Randomized Controlled Trial
}

\author{
El-Saied $\mathrm{N}^{1}$, Amer $\mathrm{M}^{1}$, Elbohoty $\mathrm{A}^{* 1}$, Saad $\mathrm{M}^{2}$ and Mansour $\mathrm{M}^{3}$ \\ ${ }^{1}$ Department of Obstetrics and Gynecology, Ain Shams University, Cairo, Egypt \\ ${ }^{2}$ Department of Medical Microbiology and Immunology, Ain Shams University, Cairo, Egypt \\ ${ }^{3}$ Department of Obstetrics and Gynecology, Ain Shams University, Fellow researcher, Cairo, Egypt
}

${ }^{*}$ Corresponding author: Elbohoty A, Department of Obstetrics and Gynecology, Ain Shams University, Maternity Hospital, Abbasiya, Cairo, Egypt, E-mail: elbohoty79@gmail.com

Citation: El-Saied N, Amer M, Elbohoty A, Saad M, Mansour M (2016) Efficacy of Vitamin C Vaginal Suppository in Treatment of Bacterial Vaginosis a Randomized Controlled Trial. J Gynecol Res 2(1): 103. doi: 10.15744/2454-3284.2.103

Received Date: May 21, 2016 Accepted Date: October 25, 2016 Published Date: October 26, 2016
Abstract
Objective: The aim of the current study was to compare the efficacy and side effects of vaginal vitamin C suppository and vaginal metronidazole in treatment of bacterial vaginosis.
Study design: Double-blind randomized controlled trial.
Methods: The study included women who presented to the outpatient gynecological clinic with a diagnosis of bacterial vaginosis by amsels criteria. The included eligible women were randomly allocated in one of two groups: group I, including women who received vitamin C vaginal suppository once daily at bed time for 6 days; and group II, including women who received metronidazole $500 \mathrm{mg}$ vaginal suppository once daily at bed time for 6 days. All included women were reviewed in 8-14 days after completion of treatment for reevaluation.
Results: The post-treatment rates of positive clue cells were, however, significantly lower among women of group I [Vitamin C Group] when compared to those of group II [Metronidazole Group]. The cure rate (defined as a Nugent score less than 4) was higher in women of group I; the difference, however, did not reach statistical significance.
Conclusion: Vaginal vitamin C suppositories seem to have similar efficacy to vaginal metronidazole suppository in treatment of bacterial vaginosis.
Keywords: Bacterial vaginosis; Vitamin C suppository; Ascorbic acid; Metronidazole

\section{Introduction}

Bacterial vaginosis (BV) is a common gynecological condition that affects nearly one-third of women [1]. BV is an evident risk factor for preterm labor, preterm prelabor rupture of the membranes (PPROM), chorioamnionitis and postpartum infection [2]. $\mathrm{BV}$ is also associated with pelvic inflammatory disease (PID) and postoperative vaginal vault infection [3]. The etiology underlying BV remains not totally clear. The current concept explaining bacterial vaginosis relies on alteration in the vaginal microbial system with depletion of the lactic acid-producing lactobacilli and remarkable abundance of anerobes [4]. The standard treatment regimens for BV are anti-anerobic agents including both metronidazole and clindamycin [5]. Metronidazole is the treatment of choice for BV [6]. Metronidazole can effectively be given through either oral or vaginal routes. Vaginal route of metronidazole is featured by the much lower systemic adverse effects associated with oral administration [7]. Although anti-anerobic antimicrobial treatment, in general, and metronidazole, in particular, has been proven to be effective in treatment of BV, a more physiological approach is to restore vaginal acidity (which is disturbed by the depletion of lactobacilli) which should suppress the overgrowth of vaginal microbial anerobes [8]. Lactic acid appears to be a reasonable choice, since it is the acid naturally produced. When it was tried as a vaginal acidifying agent, however, it was found to have a short duration of action [9]. Ascorbic acid (vitamin C) was then tried. Initial results with the use of vitamin $\mathrm{C}$ as a vaginal acidifying agent in treatment of BV were highly promising [10-12]. The aim of the current trial was to compare the efficacy and side effects of vaginal vitamin $\mathrm{C}$ suppository and vaginal metronidazole in treatment of BV.

\section{Methods}

This double-blind randomized controlled trial (RCT) was conducted at Ain Shams University Maternity Hospital during the period 
between May 2012 and January 2013. The study protocol was in agreement with the Declaration of Helsinki for Ethical Medical Research (last updated in Brazil, 2013) had been approved by the Ethical Research Committee of Obstetrics and Gynecology Department, Ain Shams University. The study included women who presented to the outpatient gynecological clinic with symptoms suggestive of bacterial vaginosis and were diagnosed by applying the Amsel criteria, through presence of at least 3 of the following 4 criteria: (1) homogeneous, thin, grayish-white discharge that smoothly coats the vaginal walls; (2) vaginal $\mathrm{pH}>4.5$; (3) positive whiff-amine test [defined as the presence of a fishy odor when a drop of $10 \%$ potassium hydroxide is added to a sample of vaginal discharge; (4) presence of clue cells on saline wet mount at a minimum percentage of $20 \%$ among epithelial cells [13]. Clue cells are vaginal epithelial cells studded with adherent coccobacilli that are best appreciated at the edge of the cell. The diagnosis of BV is confirmed using Gram's stain. The Gram-stained smear is evaluated using Nugent scoring system (Table1) [14]. Women who were pregnant, were high risk for STDs (having more than one partner, working in sex industry), were known to have chronic gynecologic malignancy, had chronic medical disorders that adversely impact patient's immunity (e.g. diabetic women and those on long-term steroid therapy), those who recently received antibiotic treatment, or recently used topical antiseptic preparation, and those who had vaginal bleeding were not included in the current study. All participating women signed informed written consent after thorough explanation of the purpose and procedures of the study. On presentation, the approached women were examined using a sterile speculum. Presence and features of vaginal discharge was noted. The vaginal fluid (or discharge) was retrieved for: (1) $\mathrm{pH}$ assessment using a $\mathrm{pH}$ indicator strip; (2) application of $10 \%$ potassium hydroxide; (3) saline wet mount preparation for direct microscopic examination (under 100 magnification power); and (4) Gram staining (women with Gram -ve diplococci, the woman were not recruited in the study). The included eligible women (who have evidence of BV) were randomly allocated in one of two groups: group I, including women who received vitamin $\mathrm{C}$ vaginal suppository once daily at bed time for 6 days; and group II, including women who received metronidazole $500 \mathrm{mg}$ vaginal suppository [Amrizole ${ }^{\varpi}$, Amriya Pharmaceutical Company, Alexandria, Egypt] once daily at bed time for 6 days. The vitamin C vaginal suppositories were prepared at the Industrial Pharmacy Department, Ain Shams University. Each suppository contained ascorbic acid (500 mg), dispersing agent (50 mg), polysorbate (80 $\mathrm{mg}$ ) in a base of mucoadhesive form ( $3 \mathrm{~g})$ which is not irritant and slowly released in vagina. Both preparations were encased in sealed opaque serially-numbered envelops. The allocation table was kept with the main supervisor and was only released at the final statistical analysis. All included women were reviewed in 8-14 days after completion of treatment for reevaluation. Vaginal swabs were retaken and subjected to Gram staining and Nugent scoring system as an objective test of cure (Table 1).

\begin{tabular}{|c|c|c|c|}
\hline Score & $\begin{array}{c}\text { Lactobacillus } \\
\text { Morphotypes }\end{array}$ & $\begin{array}{c}\text { Gardnerella } \\
\text { and Bacteroides } \\
\text { Morphotypes }\end{array}$ & $\begin{array}{c}\text { Curved Gram- } \\
\text { Variable Rods }\end{array}$ \\
\hline $\mathbf{0}$ & $4+$ & 0 & 0 \\
\hline $\mathbf{1}$ & $3+$ & $1+$ & $1+$ or $2+$ \\
\hline $\mathbf{2}$ & $2+$ & $2+$ & $3+$ or $4+$ \\
\hline $\mathbf{3}$ & $1+$ & $3+$ & \\
\hline $\mathbf{4}$ & 0 & $4+$ & \\
\hline
\end{tabular}

Score: 7-10: bacterial vaginosis

Score: 4-6: intermediate (if clue cells are present on wet mount preparation, a diagnosis of BV is made)

Score 0-3: normal

Table 1: Nugent Scoring System for Diagnosis of Bacterial Vaginosis [14]

\section{Sample size justification}

Sample size was calculated using EpiInfo version 7.0, setting the two-sided confidence level at 95\% and the power at 80\%. Data from literature showed the cure rates of BV exceed $80 \%$ with vaginal metronidazole and were nearly 55\% with ascorbic acid $[12,15]$. Calculation according to these values produced a minimal sample size 66 women in each group. Assuming a dropout rate of $10 \%$, a minimum sample size of 75 cases was needed in each group.

\section{Statistical methods}

Statistical analysis was performed using SPSS ${ }^{\circledast}$ for Windows ${ }^{\circledast}$ version 20.0 and Microsoft $^{\circledast}$ Excel $^{\circledR}$ version 2010 . Difference between two groups was estimated using independent student's t-test (for numeric parametric variables), Mann-Whitney's U-test (for numeric non-parametric variables), or chi-squared test (for categorical variables). Yates' continuity correction was applied to chisquared test, whenever one or more of the expected values was less than 5. Significance level was set at 0.05. Per-protocol analysis was performed in the current trial.

\section{Results}

A total of 164 were eligible for recruitment in the current trial. Figure 1 shows a flow-diagram of the study course.

The mean age of included women was $25.9 \pm 5.1$ years (range: $18-30$ years). The median parity was 2 (range: $0-6$ ). The mean body mass index (BMI) was $28.8 \pm 4.2 \mathrm{~kg} / \mathrm{m}^{2}$ (range: $22.3-33.1 \mathrm{~kg} / \mathrm{m}^{2}$ ). There were no significant differences between women 
of both groups regarding the age and parity (Table 2). The pre-treatment Amsel criteria for diagnosis of BV were similar in both groups (Table 3 ).

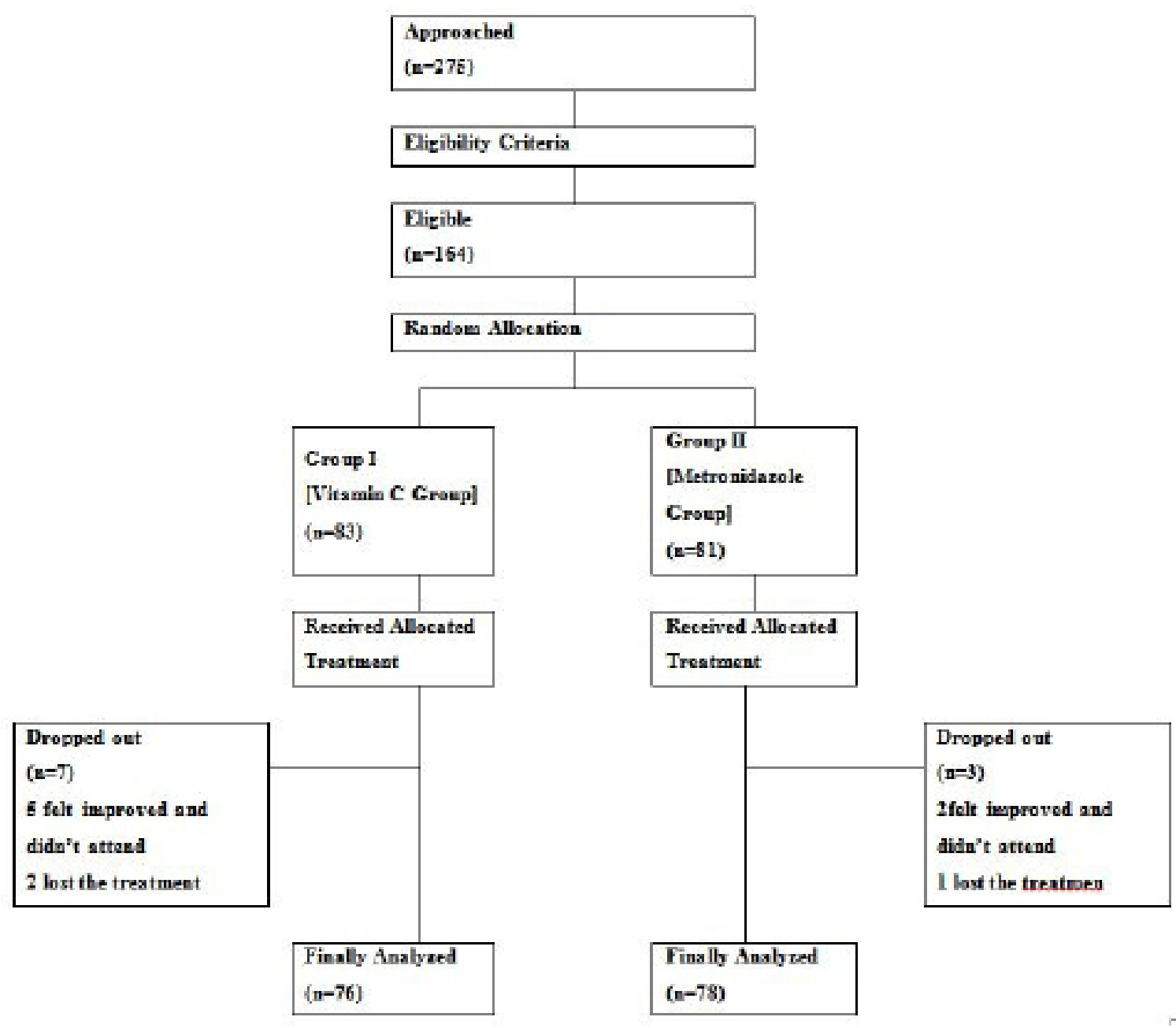

Figure 1: Flow-Diagram of the Study Course

\begin{tabular}{|c|c|c|}
\hline & $\begin{array}{c}\text { Group I } \\
\text { [Vitamin C Group] } \\
(\mathbf{n}=\mathbf{7 6})\end{array}$ & $\begin{array}{c}\text { Group I } \\
\text { [Metronidazole Group] } \\
(\mathbf{n}=78)\end{array}$ \\
\hline $\begin{array}{c}\text { Age (years) } \\
\text { Range } \\
\text { Mean } \pm \text { SD }\end{array}$ & $18-30$ & $18-30$ \\
\hline Parity & $24.7 \pm 5.2$ & $26.1 \pm 5.5$ \\
Range & $0-6$ & $0-4$ \\
Median (IQR) & $2(1-3)$ & $2(1-3)$ \\
\hline BMI (kg/m $\left.{ }^{2}\right)$ & & $24.1-33.1$ \\
Range & $22.3-32.9$ & $29.1 \pm 4.5$ \\
Mean \pm SD & $28.1 \pm 3.9$ & \\
\hline
\end{tabular}

SD standard deviation

IQR interquartile range

* Analysis using independent student's t-test

** Analysis using Mann-Whitney's U-test

NS non-significant

Table 2: Difference between Groups regarding Demographic Data

The individual post-treatment rates of Amsel criteria for diagnosis of BV were similar in both groups for the characteristic vaginal discharge, vaginal $\mathrm{pH}>4.5$ and positive Whiff test. The post-treatment rates of positive clue cells were, however, significantly lower among women of group I [Vitamin C Group] when compared to those of group II [Metronidazole Group].

The cure rate (defined as a Nugent score less than 4) was higher in women of group I; the difference, however, did not reach statistical significance [59/76 (77.6\%) vs. 50/78 (64.1\%), respectively, $\mathrm{p}=0.065$; absolute risk reduction $($ ARR $)=13.5 \%$, number needed to treat $(\mathrm{NNT})=7]$ (Table 4$)$ (Figure 2) . 


\begin{tabular}{|c|c|c|c|}
\hline Pre-Treatment & $\begin{array}{c}\text { Group I } \\
\text { [Vitamin C Group] } \\
(\mathbf{n}=76)\end{array}$ & $\begin{array}{c}\text { Group I } \\
\text { [Metronidazole Group] } \\
(\mathbf{n}=78)\end{array}$ & $\mathbf{P}^{*}$ \\
\hline \multicolumn{3}{|c|}{ Amsel Criteria } \\
\hline Characteristic discharge & $74(97.4 \%)$ & $75(96.2 \%)$ & 0.976 (NS) \\
\hline Vaginal pH $>\mathbf{4 . 5}$ & $76(100 \%)$ & $77(98.7 \%)$ & $0.990(\mathrm{NS})$ \\
\hline Positive Whiff test & $73(96.1 \%)$ & $76(97.4 \%)$ & $0.976(\mathrm{NS})$ \\
\hline Positive clue cells & $69(90.8 \%)$ & $68(87.2 \%)$ & 0.475 (NS) \\
\hline
\end{tabular}

Data presented as number (percentage)

* Analysis using continuity-corrected chi-squared test

NS non-significant

Table 3: Difference between Groups regarding Pretreatment Amsel Criteria for Diagnosis of BV

\begin{tabular}{|c|c|c|c|}
\hline Pre-Treatment & $\begin{array}{c}\text { Group I } \\
\text { [Vitamin C Group] } \\
(\mathbf{n}=\mathbf{7 6})\end{array}$ & $\begin{array}{c}\text { Group I } \\
\text { [Metronidazole Group] } \\
(\mathbf{n}=78)\end{array}$ & $\mathbf{P}^{*}$ \\
\hline \multicolumn{3}{|c|}{ Amsel Criteria } \\
\hline Characteristic discharge & $25(32.9 \%)$ & $16(20.5 \%)$ & 0.082 (NS) \\
\hline Vaginal pH $>\mathbf{4 . 5}$ & $44(57.9 \%)$ & $52(66.7 \%)$ & 0.261 (NS) \\
\hline Positive Whiff test & $22(28.9 \%)$ & $23(29.5 \%)$ & 0.941 (NS) \\
\hline Positive clue cells & $14(18.4 \%)$ & $31(39.7 \%)$ & $0.004(\mathrm{~S})$ \\
\hline Cure rate & $59(77.6 \%)$ & $50(64.1 \%)$ & $0.065(\mathrm{NS})$ \\
\hline
\end{tabular}

Data presented as number (percentage)

* Analysis using continuity-corrected chi-squared test

${ }^{* *}$ Cure rates defined by a Nugent score $<4$

NS non-significant - S significant

Table 4: Difference between Groups regarding Post-treatment Amsel Criteria for Diagnosis of BV

\section{aroup I [Vitamin C Group] G Group II [Metronidazole Group]}

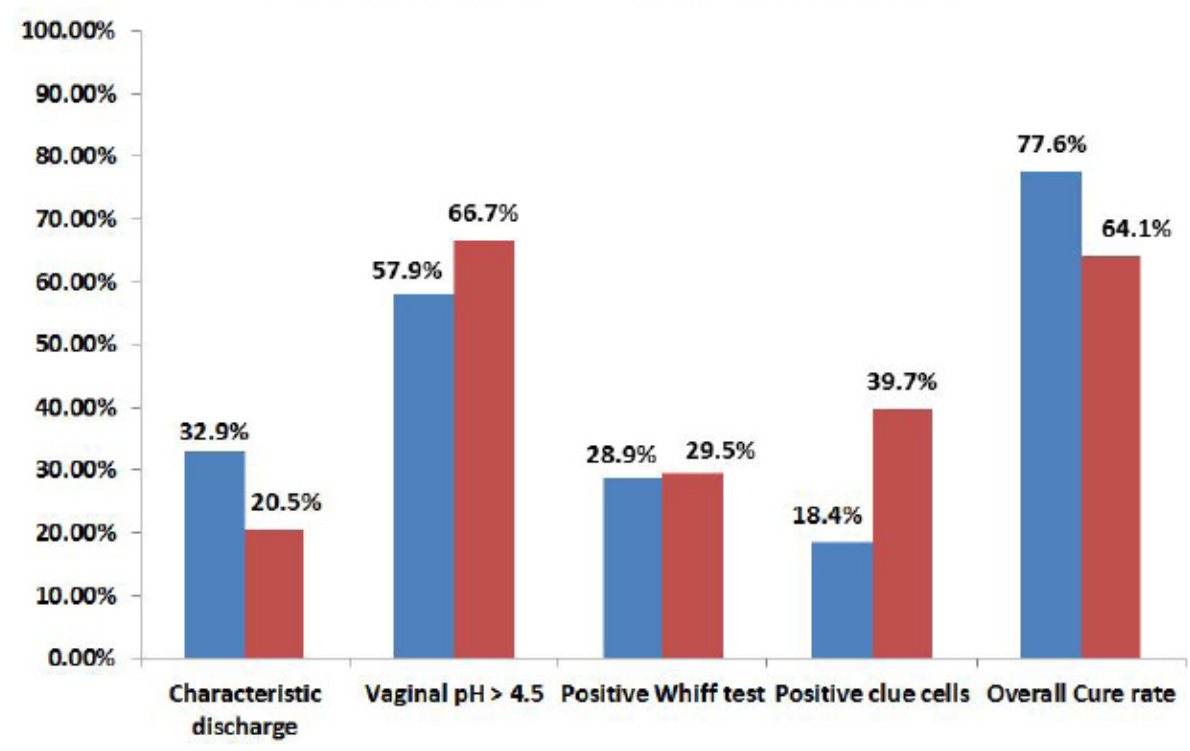

Figure 2: Bar-Chart showing Difference between Groups regarding Post-treatment Amsel Criteria for Diagnosis of BV

The rates of burning, itching, vulvovaginal candidiasis, and cystitis were comparable in both groups. The rate of nausea, however, was significantly higher among women of group II (Table 5).

\begin{tabular}{|c|c|c|c|}
\hline \multirow{2}{*}{ Pre-Treatment } & $\begin{array}{c}\text { Group I } \\
\text { [Vitamin C Group] } \\
(\mathbf{n}=\mathbf{7 6})\end{array}$ & $\begin{array}{c}\text { Group I } \\
\text { [Metronidazole Group] } \\
(\mathbf{n}=78)\end{array}$ & $\mathbf{P}^{*}$ \\
\hline \multicolumn{3}{|c|}{ Adverse Effects } \\
\hline Burning & $3(3.9 \%)$ & $4(5.1 \%)$ & 0.972 (NS) \\
\hline Itching & $3(3.9 \%)$ & $5(6.4 \%)$ & 0.745 (NS) \\
\hline Candidiasis & $1(1.3 \%)$ & $4(5.1 \%)$ & 0.379 (NS) \\
\hline
\end{tabular}




\begin{tabular}{|l|c|c|c|}
\hline Pre-Treatment & $\begin{array}{c}\text { Group I } \\
{[\text { Vitamin C Group] }} \\
(\mathbf{n = 7 6 )}\end{array}$ & $\begin{array}{c}\text { Group I } \\
{[\text { Metronidazole Group] }} \\
(\mathbf{n = 7 8 )}\end{array}$ & $\mathbf{P}^{*}$ \\
\hline \multicolumn{3}{|c|}{ Adverse Effects } \\
\hline Cystitis & $1(1.3 \%)$ & $3(3.8 \%)$ & $0.631(\mathrm{NS})$ \\
\hline Nausea & $0(0 \%)$ & $6(7.7 \%)$ & $0.04(\mathrm{~S})$ \\
\hline
\end{tabular}

\section{Discussion}

The current study showed a comparable efficacy of vitamin C vaginal suppositories and vaginal metronidazole for treatment of BV. The cure rate (defined as a Nugent score $<4$ ) was even higher (but not to a significant level) in those who received vaginal vitamin C suppositories. The individual Amsel criteria evaluated for post-treatment were similar in both groups of women, except for presence of clue cells, which were significantly less in women who received vaginal vitamin C suppositories. Indeed, the presence of clue cells is the most specific criterion among other Amsel criteria for the diagnosis of BV [16-18].

Similar findings were observed by many other studies. In a study conducted by Peterson, et al. the cure rate of BV with vaginal ascorbic acid reached $86 \%$ [12]. In an earlier study conducted by Livengood, et al. the cure rates reached 77\% [17].

The administration of metronidazole (or any other anti-anerobic agent), despite being effective, disturbs the vaginal flora and induced microbial resistance, particularly when given frequently to BV which commonly relapses [18]. Administration of vaginal ascorbic acid avoids such sequelae [19].

In the current study, both vitamin $\mathrm{C}$ and metronidazole have similar rates of adverse effects including burning, itching, and candidiasis. The rates of nausea, however, were significantly higher with metronidazole even through the vaginal route. This latter observation is another feature of vaginal vitamin C over metronidazole. Similar findings regarding comparable drug-related adverse effects were reported by other studies [20-22].

The current study is advantaged by being a double-blind randomized controlled trial on a justified sample size regarding the efficacy. The study as regards the results of the adverse effects was, however, underpowered, due to the relative infrequency of such adverse effects.

Furthermore, vitamin C suppositories need to be evaluated regarding the rates of recurrence and its role in treatment of recurrent BV.

\section{Reference}

1. Allsworth JE, Peipert JF (2007) Prevalence of bacterial vaginosis: 2001-2004 National Health and Nutrition Examination Survey data. Obstet Gynecol 109: 11420.

2. Lin KW, LoBrano MB (2009) Screening for bacterial vaginosis in pregnancy to prevent preterm delivery. Am Fam Physician 79: 697-8.

3. Larsson PG, Carlsson B (2002) Does pre- and postoperative metronidazole treatment lower vaginal cuff infection rate after abdominal hysterectomy among women with bacterial vaginosis? Infect Dis Obstet Gynecol 10: 133-40.

4. Swidsinski A, Mendling W, Loening-Baucke V, Ladhoff A, Swidsinski S, et al. (2005) Adherent biofilms in bacterial vaginosis. Obstet Gynecol 105: 1013-23.

5. Cherpes TL, Wiesenfeld HC, Melan MA, Kant JA, Cosentino LA, et al. (2006) The associations between pelvic inflammatory disease, Trichomonas vaginalis infection, and positive herpes simplex virus type 2 serology. Sex Transm Dis 33: 747-52.

6. Schwebke JR, Desmond R (2007) A randomized trial of metronidazole in asymptomatic bacterial vaginosis to prevent the acquisition of sexually transmitted diseases. Am J Obstet Gynecol 196: 517. e1-6.

7. Centers for Disease Control and Prevention (CDC) (2015) Sexually-transmitted diseases: treatment guidelines. Mortality and Morbidity Weekly Report (MMWR), Spanish.

8. Krasnopolsky VN, Prilepskaya VN, Polatti F, Zarochentseva NV, Bayramova GR, et al. (2013) Efficacy of vitamin C vaginal tablets as prophylaxis for recurrent bacterial vaginosis: a randomised, double-blind, placebo-controlled clinical trial. J Clin Med Res 5: 309-15.

9. O'Hanlon DE, Moench TR, Cone RA (2011) In vaginal fluid, bacteria associated with bacterial vaginosis can be suppressed with lactic acidbut not hydrogen peroxide. BMC Infect Dis 11: 200.

10. Welch C, Baker K (2015) The effectiveness of intravaginal vitamin C versus placebo for the treatment of bacterial vaginosis: a systematic review protocol. JBI Database System Rev Implement Rep 13: 96-113.

11. Steyn PS, Odendaal HJ, Schoeman J, Stander C, Fanie N, et al. (2003) A randomised, double-blind placebo-controlled trial of ascorbic acid supplementation for the prevention of preterm labour. J Obstet Gynaecol 23: 150-5.

12. Petersen EE, Genet M, Caserini M, Palmieri R (2011) Efficacy of vitamin C vaginal tablets in the treatment of bacterial vaginosis: a randomised, double blind, placebo controlled clinical trial. Arzneimittelforschung 61: 260-5.

13. Amsel R, Totten PA, Spiegel CA, chen kc, eschenbach d, et al. (1983) Nonspecific vaginitis. Diagnostic criteria and microbial and epidemiologic associations. Am J Med 74: 14-22. 
14. Nugent RP, Krohn MA, Hillier SL (1991) Reliability of diagnosing bacterial vaginosis is improved by a standardized method of Gram stain interpretation. J Clin Microbiol 29: 297-301.

15. Thulkar J, Kriplani A, Agarwal N (2012) A comparative study of oral single dose of metronidazole, tinidazole, secnidazole and ornidazole in bacterial vaginosis. Indian J Pharmacol 44: 243-5.

16. Hemalatha R, Ramalaxmi BA, Swetha E, Balakrishna N, Mastromarino P (2013) Evaluation of vaginal pH for detection of bacterial vaginosis. Indian J Med Res 138: 354-9.

17. Livengood CH, Soper DE, Sheehan KL, Fenner DE, Martens MG, et al. (1999) Comparison of once-daily and twice-daily dosing of 0.75\% metronidazole gel in the treatment ofbacterial vaginosis. Sex Transm Dis 26: 137-42.

18. Owen MK, Clenney TL (2004) Management of vaginitis. Am Fam Physician 70: 2125-32.

19. Tateo S (2009) Modification of the vaginal flora: effectiveness of local therapy with Feminella Vagi C (ascorbic acid). Akush Ginekol (Sofiia) 1: 48.

20. Nikolov A, Masseva A, Shopova E, Georgiev S (2012) Multipurpose treatment of vaginal infections. Akush Ginekol (Sofiia) 51: $10-4$.

21. Cooper NA, Moores R (2014) East London Preterm Prevention Collaboration. A review of the literature regarding nutritional supplements and their effect on vaginal flora and preterm birth. Curr Opin Obstet Gynecol 26: 487-92.

22. Schoeman J, Steyn PS, Odendaal HJ, Grové D (2005) Bacterial vaginosis diagnosed at the first antenatal visit better predicts preterm labour than diagnosis later in pregnancy. J Obstet Gynaecol 25: 751-3.

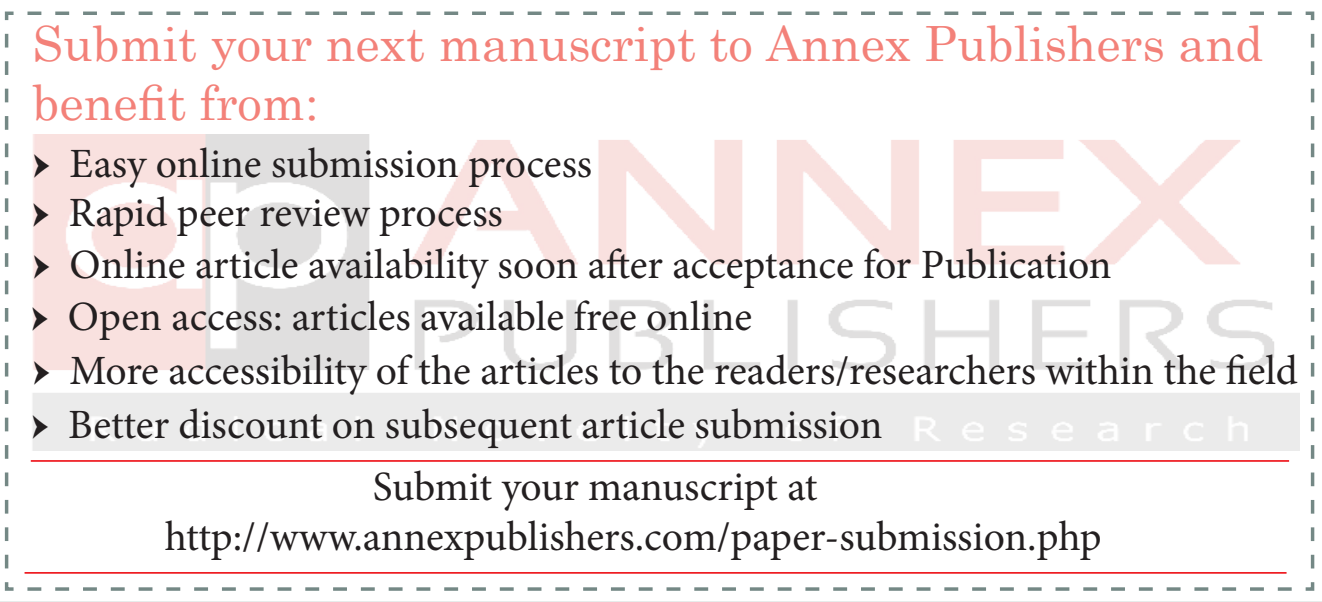

